\title{
Genetic transformation of western clover (Trifolium occidentale D. E. Coombe.) as a model for functional genomics and transgene introgression in clonal pasture legume species
}

Kim A Richardson ${ }^{1 *}$, Dorothy A Maher ${ }^{1,2}$, Chris S Jones ${ }^{1,2}$ and Greg Bryan ${ }^{1}$

\begin{abstract}
Background: Western clover (Trifolium occidentale) is a perennial herb with characteristics compatible for its development as an attractive model species for genomics studies relating to the forage legume, white clover (Trifolium repens). Its characteristics such as a small diploid genome, self-fertility and ancestral contribution of one of the genomes of $T$. repens, facilitates its use as a model for genetic analysis of plants transformed with legume or novel genes.

Results: In this study, a reproducible transformation protocol was established following screening of T. occidentale accessions originating from England, Ireland, France, Spain and Portugal. The protocol is based upon infection of cotyledonary explants dissected from mature seed with the Agrobacterium tumefaciens strain GV3101 carrying vectors which contain the bar selection marker gene. Transformation frequencies of up to $7.5 \%$ were achieved in 9 of the 17 accessions tested. Transformed plants were verified by PCR and expression of the gusA reporter gene, while integration of the T-DNA was confirmed by Southern blot hybridisation and segregation of progeny in the $T_{1}$ generation.

Conclusions: Development of this protocol provides a valuable contribution toward establishing T. occidentale as a model species for white clover. This presents opportunities for further improvement in white clover through the application of biotechnology.
\end{abstract}

Keywords: Agrobacterium-mediated transformation, Trifolium occidentale, Genetic transformation, Organogenic regeneration, Accession

\section{Background}

White clover (Trifolium repens L., Figure 1a) is the most extensively used perennial legume in temperate grazed pastoral systems grown for its nutritional value and ability to fix atmospheric nitrogen [1,2]. This stoloniferous, clonal herb [3] originating from the grasslands of Europe, Western Asia and North Africa has an allotetraploid $(2 \mathrm{n}=4 \mathrm{x}=32)$ genome derived from two diploid ancestors T. pallescens $(2 \mathrm{n}=2 \mathrm{x}=16)$ and $T$. occidentale $(2 \mathrm{n}=2 \mathrm{x}=$ 16) [4]. The conventional breeding techniques used for

\footnotetext{
* Correspondence: kim.richardson@agresearch.co.nz

${ }^{1}$ AgResearch Ltd, Grasslands Research Centre, Private Bag 11008, Palmerston North 4442, New Zealand

Full list of author information is available at the end of the article
}

plant improvement have resulted in the release of many commercial cultivars, however, it is now recognised that biotechnology approaches hold the promise of additional genetic gain in this species through the introduction of novel traits [5].

Expression of heterologous genes in white clover has identified the potential for crop improvement through biotechnology including the accumulation of fructan as a storage carbohydrate [6], increased accumulation of sulphur rich amino acids in foliar tissues $[7,8]$, insect pest resistance through plants expressing a modified cry1Ba [9], Alfalfa Mosaic Virus resistance in field trial experiments [10] and the investigation of white clover as a delivery mechanism for edible vaccines [11]. 

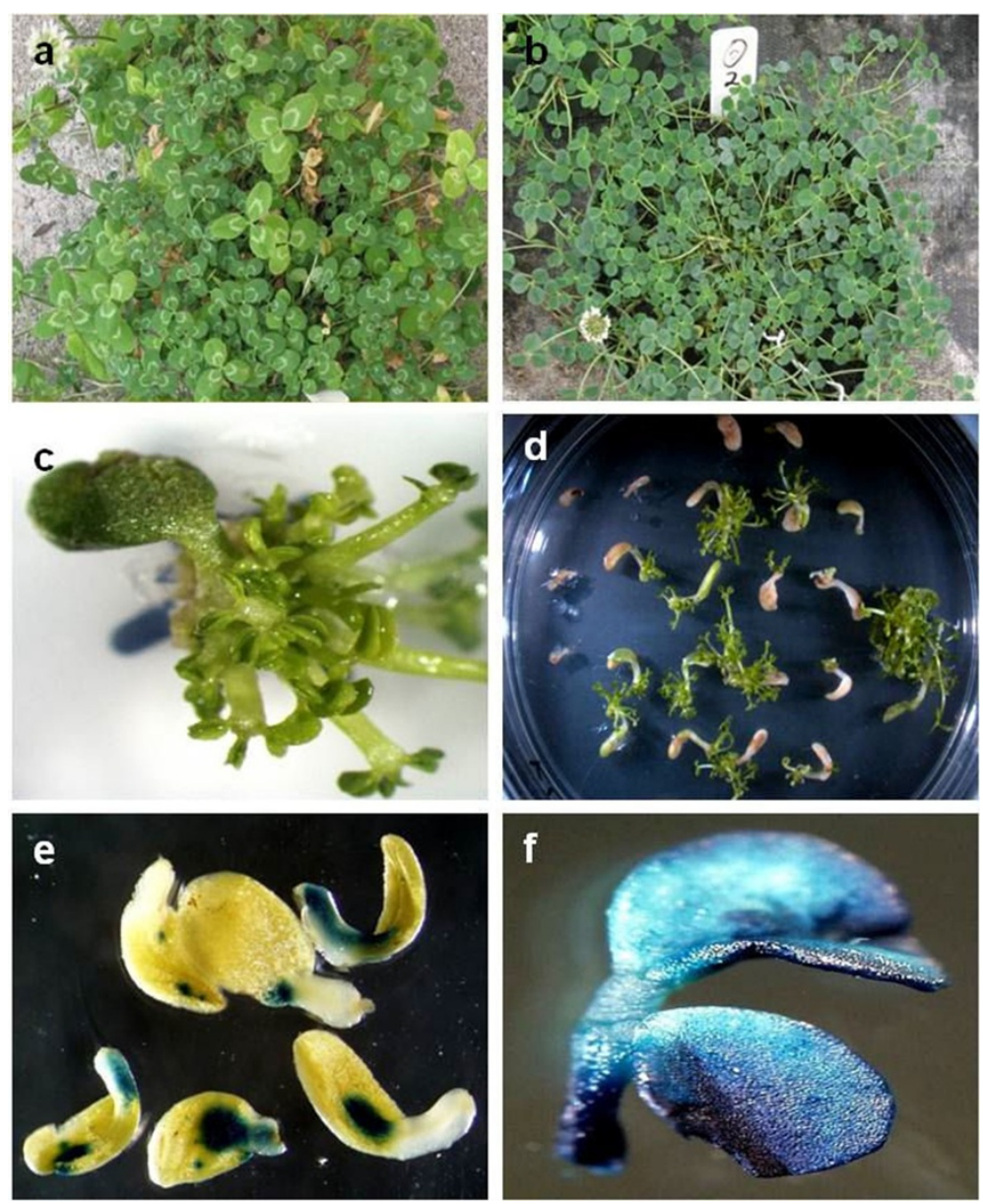

Figure 1 Western clover (T. occidentale), shoot regeneration and transformation. (a) white clover (T. repens); compared to (b) T. occidentale (c) prolific regeneration of shoots from an AZ4270 cotyledon following three weeks culture on 1C; (d) shoot regeneration under ammonium glufosinate selection following Agrobacterium-mediated transformation of cotyledon explants; (e) transient GUS expression on cotyledonary explants three days after inoculation with Agrobacterium broth; (f) GUS activity in a trifoliate leaf excised from stably transformed plants approximately eight weeks after transformation.

In recent years significant genomic resources both for white clover and model legume species have become available [12-14]. While transformation protocols for white clover are readily available [15-18]; the ability to exploit these resources is limited by a genetic composition resulting in self incompatiblility, cross pollination, allotetraploidy and amphidiploid inheritance with high levels of heterozygosity making the application of genomic technologies problematic at best [19]. Such characteristics are complicating factors for the genetic analysis of transgene inheritance in white clover and are an issue which is common to many crop species. Whereas elite cultivars are generally developed from multiple parents and therefore represent a heterogeneous mixture of heterozygous individuals, the inter-crossing between closely related genotypes - as required for the development of transgenic progenies - often leads to a loss of heterozygosity and inbreeding depression $[20,21]$.
To overcome this problem, western clover (T. occidentale, Figure $1 \mathrm{~b}$ ) appeals as a model for gene expression and determination of gene function in white clover. T. occidentale is diploid, possesses a small genome (approximately $0.5 \mathrm{pg} / 1 \mathrm{C}$ ) of similar size to Medicago truncatula and Lotus japonicas [22] and is a proposed progenitor of $T$. repens, therefore, most genes will be highly related. It has both self-fertile and self-incompatible accessions, a relatively short generation time and is able to fix nitrogen in symbiotic association with Rhizobium bacteria [19]. Its natural habitat is along coastal regions of Europe and the British Isles exposed to the Gulf Stream and until its description as a new species was regarded as a variety of white clover [23]. Tools such as the establishment of EMS mutants [19] and a genome which is currently being sequenced [24] make T. occidentale an ideal candidate as a model species for functional genomics in pasture legumes. 
Ploidy manipulation by in vitro treatment with colchicine has been used in kiwifruit and peanut as a breeding strategy to generate hybrids between closely related diploid and tetraploid species [25,26]. When applied to T. occidentale this strategy allows the hybridisation of T. occidentale transgenics directly with white clover. This hybridisation approach following characterisation of the transgene in the $T$. occidentale model system provides a viable strategy for the rapid transfer of new traits into commercially relevant germplasm. In addition, reports of the generation of a synthetic white clover through the hybridisation of $T$. occidentale with $T$. pallescens [4] and a novel hybrid from $T$. occidentale with T. nigrescens [27] offer exciting possibilities for the introgression of GM traits into a range of novel clover germplasm. The use of T. occidentale as a genetic bridge to other Trifolium species provides significant advantages for GM breeding in forage legumes.

Here, we report on the transformation capacity of $T$. occidentale accessions collected from England, Ireland, France, Portugal and Spain. In these experiments we: (1) determined optimal conditions for organogenic regeneration of an English accession, (2) assessed regeneration in accessions from England, Ireland and France, (3) performed Agrobacterium-mediated transformation experiments with seventeen accessions to regenerate transformed plants expressing a gusA reporter gene, (4) characterised the plants by Southern blot hybridisation and PCR analysis to demonstrate stable integration of the T-DNA, and (5) examined the segregation of the transgene in $\mathrm{T}_{1}$ progeny.

To our knowledge this is the first description of a complete protocol for the reliable production of transformed T. occidentale. As with white clover; the system utilizes cotyledons dissected from mature seed as an explant for plant regeneration. Rapid regeneration was achieved via direct organogenesis and plants were recovered from a number of the accessions tested.

\section{Results and discussion}

\section{Shoot regeneration}

Primary requirements for plant transformation include the availability of target tissues competent for plant regeneration at high frequency, a method to introduce genetic constructs into regenerable cells and a procedure to select and regenerate plants at a satisfactory frequency [28]. Based upon our experience with white clover, we tested the ability of cotyledonary explants to regenerate on a range of culture media containing different plant growth regulator (PGR) combinations. Accession AZ4270 was used in the first phase of this process to identify an optimal growth medium for the regeneration of plants from dissected cotyledons.
PGR treatment combinations comprising cytokinin BA or TDZ and auxin IBA or NAA were tested. Each combination was developed around PGR regimes cited in successful legume tissue culture protocols. These included those described for $T$. repens [16,29], Medicago truncatula [30,31] and Lotus japonicus [32,33]. PGR treatment combinations comprised; (1) BA and IBA, (2) BA and NAA, (3) TDZ and IBA and (4) TDZ and NAA at varying concentrations. The experiment used 80 cotyledons per treatment (four replicate plates of 20 explants per plate) for each of the 42 different media.

Explants were cultured on plant growth media for four weeks without subculture. Regeneration frequencies (number of explants regenerating per plate) were assessed at this time (Figure 2, Additional file 1: Table S1). A relatively uniform production of plantlets with high levels of regeneration (86-94\%) was encountered over the range of PGR combinations and concentrations; however, there were clear visual differences in the fitness and average number of shoots produced per explant. Therefore, we also examined the vigor, hyperhydricity and average number of shoots regenerating per explant in each treatment (data not shown). Treatments resulting in the regeneration of greater than five, morphologically normal, shoots per explant (Figure 1c) were an important parameter in this assessment.

Shoots regenerating in Treatment 1 were more robust in comparison to those from Treatments 2,3 or 4 . Hyperhydricity was encountered at slightly higher levels in Treatment 2 compared to Treatment 1 and at unacceptably high levels in Treatments 3 and 4 where TDZ was utilized as the source of cytokinin. This is in contrast with Ding et al. [15] who report high levels of plant regeneration in five Trifolium species using TDZ, although the phenomena of hyperhydricity induced by TDZ has been reported for other plant species [34-36].

Medium C from Treatment 1 (1C, $0.5 \mathrm{mgl}^{-1} \mathrm{BA}, 1.0 \mathrm{mgl}^{-1}$ IBA) resulted in superior regeneration of $T$. occidentale shoots. To determine the utility of $1 \mathrm{C}$ across a range of germplasm, we tested a further 11 accessions originating from France (5), Ireland (4) and England (2) for regeneration capability. Frequencies of 75 to $98 \%$ were achieved indicating a genotype dependent response but confirming $1 \mathrm{C}$ as a suitable regeneration medium for this species (Figure 3). Based on these assessments of regeneration efficiency and prolific shoot formation, Medium $1 C$ was chosen to establish a transformation system for $T$. occidentale.

Shoots recovered from each of the treatments were assessed for their ability to develop roots, under in vitro conditions following culture, on a growth regulator-free medium containing half strength MS salts and 3\% maltose. A total of 21 shoots were tested and root formation assessed after five weeks of culture. Root formation 

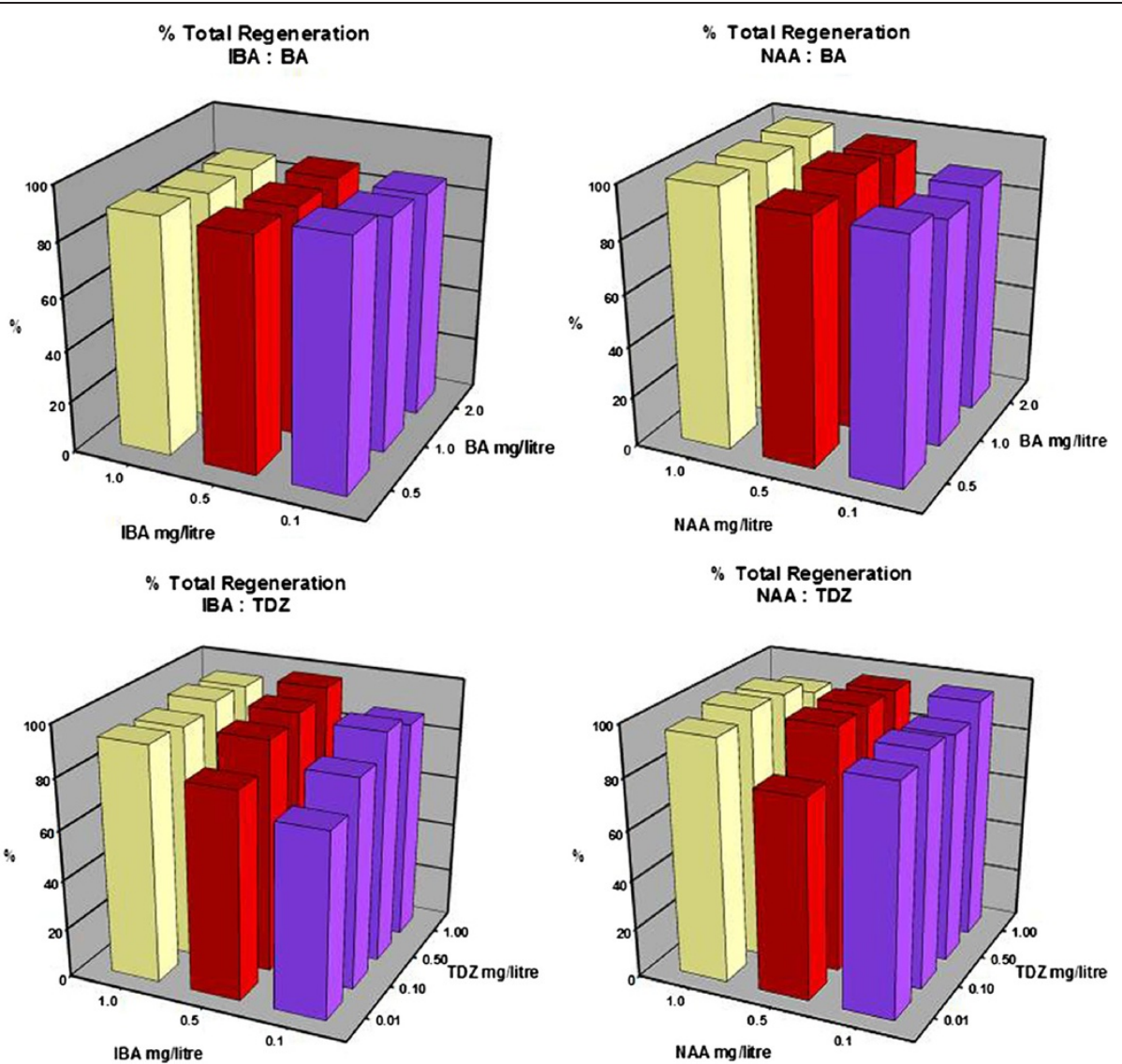

Figure 2 Influence of PGR regime on the frequency of shoot regeneration from cotyledonary explants of AZ4270. Each data point represents the mean of 4 replicate plates containing 20 explants per plate.

of $>50 \%$ was achieved in shoots from each of the media tested. Rooted plants were then transferred to the greenhouse and observed to be morphologically similar to greenhouse grown seedlings of AZ4270.

A shoot regeneration frequency of over $95 \%$ was similar to that reported for white clover on the same plant growth regulator regime at comparable concentrations [29]. Therefore, it appears that T. occidentale behaves in much the same way as $T$. repens and upwards of five shoots per explant can be expected on most media. However, using different PGRs we have found that a combination of BA and IBA is optimal for production of normal shoots at a high regeneration frequency. TDZ has often been shown to be more successful than BA for the regeneration of shoots in many plant species including some Trifolium species $[15,37]$ but this was not observed here and resulted in poor quality material that was highly hyperhydric.

\section{Agrobacterium-mediated transformation}

For T. occidentale to be a good candidate for use as a genetic model it is important that it can be easily transformed and whole plants regenerated. As legume transformation is often genotype dependent [38], a series of experiments were carried out to compare the response of 16 accessions to Agrobacterium-mediated plant transformation. These accessions, collected from 4 sites in Portugal and 12 sites in Spain, represented a range of germplasm, both selffertile and self-incompatible, showing variability in vigour and growth habit, with several displaying leaf mark characteristics similar to those of $T$. repens.

Based on the efficient regeneration achieved from AZ4270, Medium 1C was selected for use in the cocultivation and regeneration/selection phases of the transformation experiments. For comparison we also tested Medium 2D (0.5 mgl $\left.{ }^{-1} \mathrm{BA}, 0.1 \mathrm{mgl}^{-1} \mathrm{NAA}\right)$ which is used for white clover regeneration in our laboratory. Transformation was based upon protocols described for other Trifolium species [15-17] by co-cultivation of cotyledons dissected from mature seed with the Agrobacterium tumefaciens strain GV3101 harbouring the binary vector pHZBar-intGUS (Additional file 2: Figure S1) carrying the bar selection marker and the gusA reporter gene. Shoots regenerated directly from the cotyledonary axil via organogenesis in a similar manner to that described for white clover [29]. Putatively transformed plants were 


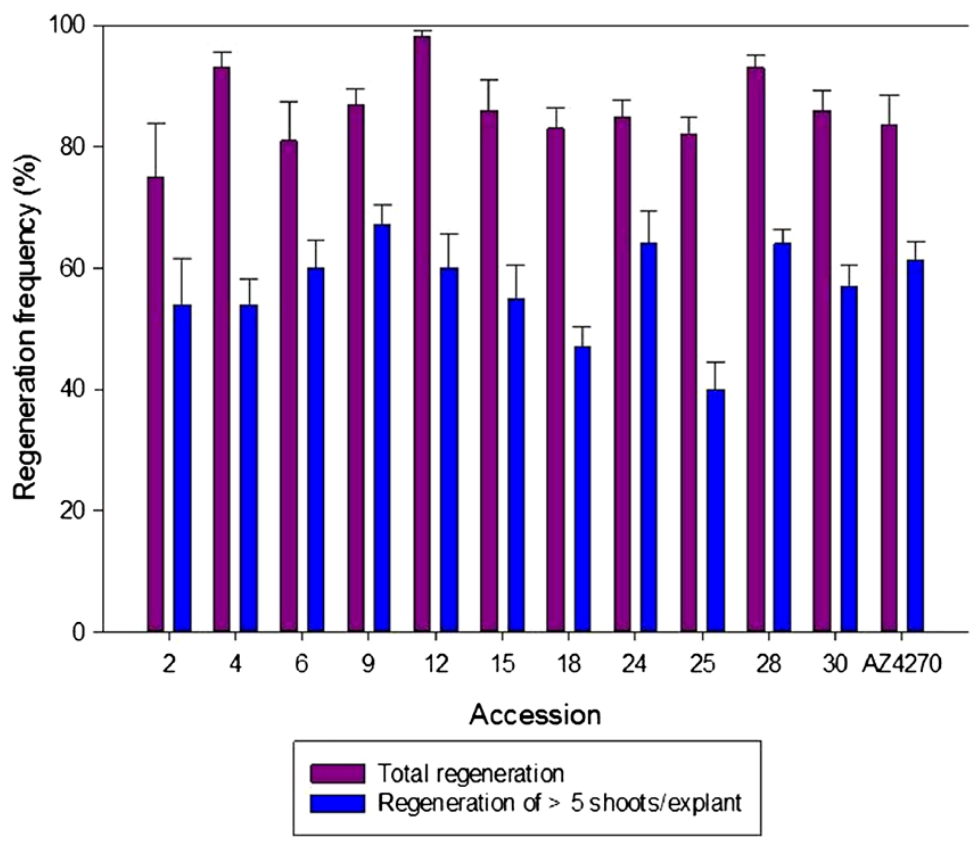

Figure 3 Regeneration frequency of eleven accessions compared to AZ4270 on medium 1C. Data were scored following four weeks of culture.

recovered from explants 4 to 6 weeks post transformation (Figure 1d).

Bacterial contamination was difficult to control in several accessions 34, 36, 39, 43, 49 and 53 where growth of explants was inhibited. These lines were discarded from further transformation assessments. This contamination appeared to arise from endogenous bacteria inherently associated with the testa of imbibed seeds and was often uncontrollable even with bacteriostatic compounds such as timentin or cefotaxime. These endophytic bacteria can be difficult to eliminate by simple surface sterilization $[39,40]$, however, such high levels of contamination are rarely encountered in commercially produced white clover seed. This high bacterial load was not unexpected as the seed used in these experiments were only one generation removed from wild populations. It is anticipated that successive seed collections in a phytosanitary environment will provide a clean source of material for transformation.

Activity of an intron containing gusA reporter gene was used to monitor transfer of T-DNAs into cells of the explant. Transient expression was observed in approximately $65 \%$ of explants, following 3 days of cocultivation (Figure 1e) indicating that the transformation parameters routinely used for white clover were also likely to be suitable for gene transfer into T. occidentale. GUS activity was also used to identify stably transformed plants (Figure 1f) and to determine the transformation frequency of accessions which ranged from 0 to 7.5 transformed plants per one hundred explants (Table 1).
Transformed plants were recovered from 9 of the 17 accessions tested with transformation frequencies obtained similar to those reported previously for white clover, red clover and subterranean clover [15]. The variable recovery of transformed plants across accessions and between the two media reflects the genotype dependent nature of transformation which is commonly encountered in many Trifolium species. For example, in AZ4270, a transformation frequency of $0.4 \%$ was obtained on medium $1 C$ while no plants were recovered on medium 2D. Similarly, no plants were recovered from accessions 32 or 38 regenerating on either media. Accessions 37, 41, 44, 52, 54 and 59 gave transformation frequencies in the range of that obtainable from AZ4270 or T. repens. Frequencies for accessions 45 and 48 were slightly higher with an average frequency of $5.4 \%$ achieved for 45 on both media whereas plants were recovered at a frequency of $2.5 \%$ on $1 \mathrm{C}$ and $7.5 \%$ on $2 \mathrm{D}$ for genotype 48 . Accession 41 was the best performing self-fertile accession with a transformation frequency of $2.7 \%$ on the $1 \mathrm{C}$ medium.

\section{Characterisation of transgenic plants}

Primary transformant $\left(\mathrm{T}_{0}\right)$ plants were assayed for integration of the T-DNA into the genome and expression of the transgene. Histochemical GUS assays and PCR, performed on leaf pieces from putatively transformed plants, were used to confirm the transgenic status of plants. Results of plants staining positive for GUS activity or by PCR analysis were combined to determine the transformation frequency. 
Table 1 Summary of transformation frequencies obtained for $T$. occidentale accessions

\begin{tabular}{|c|c|c|c|c|}
\hline Accession & Media & $\begin{array}{l}\text { Total no. } \\
\text { explants }\end{array}$ & $\begin{array}{c}\text { Total no. } \\
\text { plants }\end{array}$ & $\begin{array}{l}\text { Transformation } \\
\text { frequency }\end{array}$ \\
\hline \multirow[t]{2}{*}{ AZ4270 } & $1 C$ & 250 & 1 & 0.40 \\
\hline & $2 \mathrm{D}$ & 250 & 0 & 0.00 \\
\hline \multirow[t]{2}{*}{32} & $1 C$ & 260 & 0 & 0.00 \\
\hline & $2 \mathrm{D}$ & 260 & 0 & 0.00 \\
\hline \multirow[t]{2}{*}{37} & $1 C$ & 180 & 0 & 0.00 \\
\hline & $2 \mathrm{D}$ & 180 & 3 & 1.67 \\
\hline \multirow[t]{2}{*}{38} & $1 \mathrm{C}$ & 240 & 0 & 0.00 \\
\hline & $2 \mathrm{D}$ & 240 & 0 & 0.00 \\
\hline \multirow[t]{2}{*}{41} & $1 C$ & 150 & 4 & 2.67 \\
\hline & $2 \mathrm{D}$ & 150 & 2 & 1.33 \\
\hline \multirow[t]{2}{*}{44} & $1 C$ & 180 & 4 & 2.22 \\
\hline & $2 \mathrm{D}$ & 180 & 1 & 0.56 \\
\hline \multirow[t]{2}{*}{45} & $1 C$ & 220 & 12 & 5.45 \\
\hline & $2 \mathrm{D}$ & 220 & 12 & 5.45 \\
\hline \multirow[t]{2}{*}{48} & $1 C$ & 200 & 5 & 2.50 \\
\hline & 2D & 200 & 15 & 7.50 \\
\hline \multirow[t]{2}{*}{52} & $1 C$ & 180 & 7 & 3.89 \\
\hline & $2 \mathrm{D}$ & 180 & 4 & 2.22 \\
\hline \multirow[t]{2}{*}{54} & $1 C$ & 200 & 0 & 0.00 \\
\hline & $2 \mathrm{D}$ & 180 & 2 & 1.11 \\
\hline \multirow[t]{2}{*}{59} & $1 \mathrm{C}$ & 220 & 2 & 0.91 \\
\hline & $2 \mathrm{D}$ & 150 & 1 & 0.67 \\
\hline
\end{tabular}

The data are the means of two independent experiments.

Southern blot hybridization was used to estimate the number of T-DNA insertions, or copy number, per line. Genomic DNA was digested using EcoRV and hybridized using a non-radioactive DIG probe designed to bind to the 3' region of the gusA reporter gene situated between the EcoRV site and the Right Border of the T-DNA. This resulted in bands of greater than $2.8 \mathrm{~KB}$. An example of the hybridization patterns is shown in Figure 4. The different integration patterns indicate independent transformation events were generated. Between one and three T-DNA integrations per line were identified with 8 of the 11 lines tested showing a single insertion of the T-DNA.

\section{Segregation of $T_{1}$ progeny}

The hemizygous nature of the T-DNA insert means that characterization of transgene expression and phenotype can be problematic in the $T_{0}$ and subsequent generations of an obligate out crossing and highly heterozygous plant species such as white clover. The tetraploid genome of white clover may further complicate expression patterns. In a self-fertile diploid species it is a relatively simple process to generate genetically identical lines for analysis with plants which are homozygous for the transgene. However, in an out crossing species this generally requires cross pollination between closely related genotypes over at least two generations and is difficult to achieve without the introduction of inbreeding depression due to a loss of heterozygosity.

To overcome this difficulty the concept of "isogenic transformation" in white clover has been demonstrated as a means by which transformed and non-transformed plants may be compared in the same genetic background [41]. The method involves (i) transformation and (ii) culture, respectively, of cotyledon pairs dissected from individual seeds with the resultant plant pairs being used for a comparative analysis. But this is a rather labour intensive, time consuming approach requiring the maintenance of large numbers of non-transformed partners prior to the selection, regeneration and identification of transformed plants. Furthermore, despite being isogenic, the resulting $\mathrm{T}_{0}$ plants are hemizygous and a complicated crossing procedure is still required to establish populations which possess a homozygous transgene. Here we show that the transformation capacity of selffertile accessions of $T$. occidentale provides a viable alternative to isogenic transformation. Transformed lines of interest in the $\mathrm{T}_{0}$ generation may be identified and $\mathrm{T}_{1}$ seed populations harvested from these within 5-7 weeks following flowering.

Transmission of the transgene was demonstrated in 4 independently transformed lines derived from the selffertile accession 41 transformed with a construct designed to co-express the Diacylglycerol acyltransferase 1 gene from nasturtium and a modified oleosin gene from sesame [42]. $\mathrm{T}_{0}$ plants were grown to maturity, self-pollinated to produce seed and progeny grown to produce $T_{1}$ plants in order to confirm inheritance of the transgene in the next generation. Progeny from three lines containing a single T-DNA insert and one line containing three T-DNA insertions (as determined by Southern blot hybridization) were scored for transmission of the transgene by PCR (Table 2). The expected Mendelian inheritance, a 3:1 segregation ratio, was observed in 2 of the single copy T-DNA lines (AAT6501 and AAT6503). The third single copy T-DNA line AAT6502 did not conform to Mendelian expectations and segregated in a 2:1 ratio (Chi squared $=1.24$ ) which is indicative of a T-DNA insertion causing a lethal knockout of homozygous progeny. The 3 copy T-DNA line (AAT6505) also segregated with a 3:1 ratio (Chi squared $=$ 0.28 ) suggesting the insertion of all T-DNA's at a single, or closely linked, loci.

Seed was recovered from a further three independently transformed lines suggesting that fertility and seed set is not adversely affected in mature plants following transformation. Yields of 130 to several thousand seed per plant were achieved. The phenotype of all primary transformants and progenies appeared similar to non- 


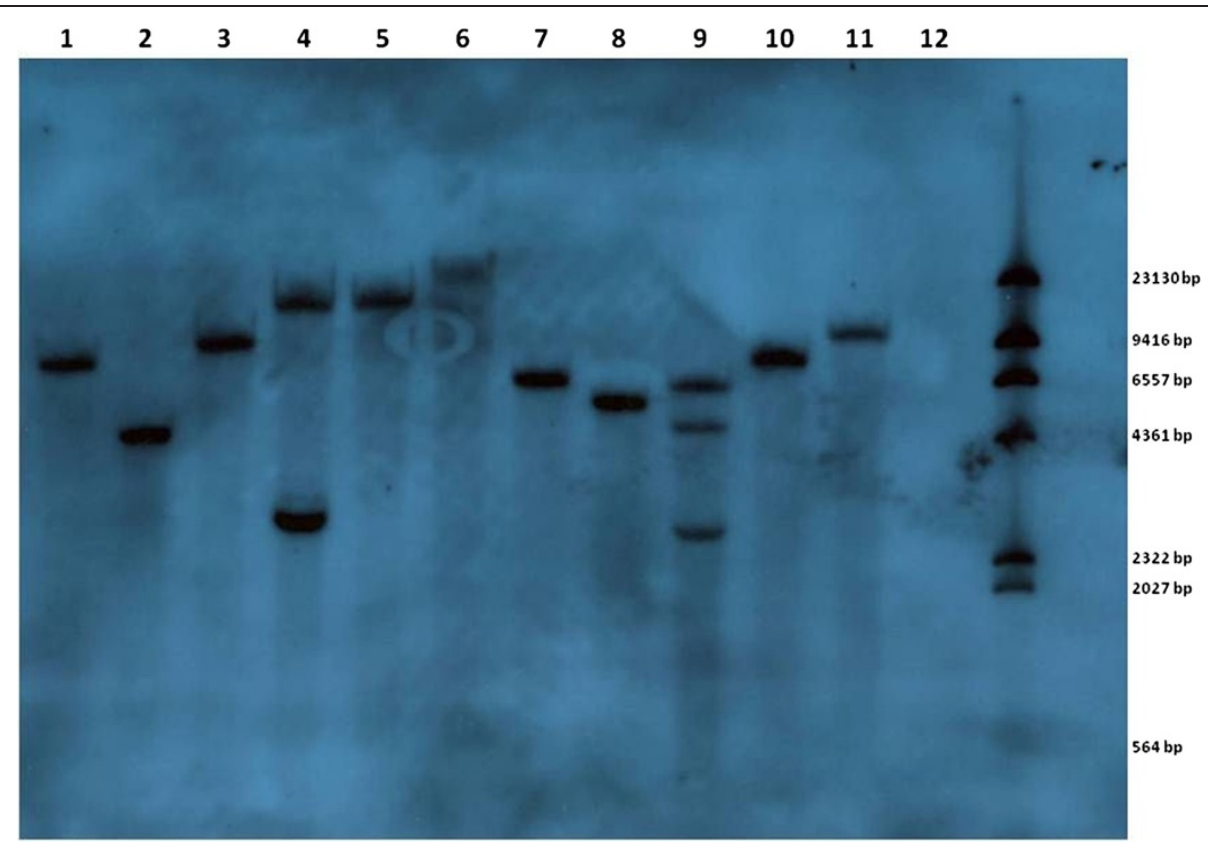

Figure 4 Southern blot hybridisation of $T$. occidentale $T_{0}$ translines. Total genomic DNA was prepared from foliar tissues of independently transformed plants and a non-transformed wild type control. DNAs were digested with the restriction enzyme EcoRV and probed with a DIGlabelled fragment of the 3' region of the gusA reporter gene. Lanes 1-11 transformed plants, lane 12 non-transformed control and lane 13 is the DIG labelled DNA Molecular Weight Marker II (Roche).

transformed control plants when grown in a contained greenhouse environment.

\section{Conclusions}

Efficient genetic transformation in nine accessions of $T$. occidentale originating from England, Portugal and Spain has been demonstrated. An optimal media has been identified for use in a protocol adapted from Voisey et al. 1994 [17] and the transformation frequencies obtained were comparable to those routinely observed for $T$. repens in our hands. Based upon the frequency of shoot regeneration achieved for the fully self-fertile accessions from England, Ireland and France it is likely that the recovery of

Table 2 Segregation of the bar selection marker in $\mathbf{T}_{1}$ progeny of $T$. occidentale translines

\begin{tabular}{cccccccc}
\hline $\begin{array}{c}\text { Plant } \\
\text { line }\end{array}$ & $\begin{array}{c}\text { Total no. } \\
\text { seedlings }\end{array}$ & Observed & Expected & $\begin{array}{c}\text { Chi- } \\
\text { square }\end{array}$ & P value \\
\hline AAT6501 & 53 & 44 & 9 & 40 & 13 & 1.63 & 0.202 \\
AAT6502 & 58 & 35 & 23 & 44 & 14 & 7.63 & 0.006 \\
AAT6503 & 56 & 43 & 13 & 42 & 14 & 0.10 & 0.758 \\
AAT6505 & 76 & 59 & 17 & 75 & 1 & 19 & $2.3 \times 10^{-58}$ \\
\hline
\end{tabular}

Presence of the bar gene was determined by PCR assay of genomic DNA isolated from leaf tissues of $\mathrm{T}_{1}$ seedlings. For AAT6501, AAT6502 and AAT6503 the expected ratio is based upon a 3:1 segregation of a single copy T-DNA at a single insertion locus and a 63:1 segregation for AAT6505 of three T-DNA's at separate insertion loci. transformed plants is possible across a wider range of germplasm than tested in these experiments. Stable inheritance of the transgene, its segregation in a Mendelian fashion and reliable seed generation was demonstrated in T. occidentale. These characteristics when coupled with an ability to hybridise with T. palescens (and other diploid clovers) offers the possibility of a viable method for the use of T. occidentale as a "genetic bridge" for the introgression of novel traits into white clover.

Development of this protocol is a significant contribution toward establishing $T$. occidentale as a genetic model allowing the study of agriculturally or biologically important questions in white clover. Its diploid genome, self-fertility and close ancestral relationship to $T$. repens combined with the availability of genomic resources underlie its potential as a model for testing gene function in Trifolium species.

\section{Materials and Methods \\ Plant material}

Seed of 28 accessions of T. occidentale (Table 3) originating from England, Ireland, France, Portugal and Spain were obtained from the Margot Forde Germplasm Centre at AgResearch. Seed of accession AZ4270 (England) was used for both shoot regeneration and transformation experiments whereas all other accessions were assessed either for regeneration or capability in Agrobacteriummediated transformation. Aliquots of up to 100 seeds 
Table $3 T$. occidentale accessions used in this study

\begin{tabular}{|c|c|c|c|c|}
\hline Accession & Collection site & Location & Fertility* & Use in this study \\
\hline AZ4270 & Cornwall & England & SF & Shoot regeneration/ Transformation \\
\hline 2 & Skerries & Ireland & SF & Shoot regeneration \\
\hline 4 & Bull Island & Ireland & SF & Shoot regeneration \\
\hline 6 & Kilmore Quay & Ireland & SF & Shoot regeneration \\
\hline 9 & St Helens & Ireland & SF & Shoot regeneration \\
\hline 12 & Mayon Cliff & England & SF & Shoot regeneration \\
\hline 15 & Mullion Cliff (Cornwall) & England & SF & Shoot regeneration \\
\hline 18 & Le Guilvinec & France & SF & Shoot regeneration \\
\hline 24 & Lampaul-Plouarzel (Brittany) & France & SF & Shoot regeneration \\
\hline 25 & Point du Corson (Brittany) & France & SF & Shoot regeneration \\
\hline 28 & Dunes St Marguerite (Brittany) & France & SF & Shoot regeneration \\
\hline 30 & Flamanville (Normandy) & France & SF & Shoot regeneration \\
\hline 32 & Leca da Palmeira & Portugal & SF & Transformation \\
\hline 34 & Villa Cha & Portugal & SF & Transformation \\
\hline 36 & Costelo do neiva & Portugal & SF & Transformation \\
\hline 37 & Carreco & Portugal & SF & Transformation \\
\hline 38 & Saxian & Spain & SF & Transformation \\
\hline 39 & Cabo Silleiro (Baredo) & Spain & SF & Transformation \\
\hline 41 & Cabo de Corrubedo lighthouse & Spain & SF & Transformation \\
\hline 43 & Punta louro lighthouse & Spain & SF & Transformation \\
\hline 44 & Praia de Larino & Spain & $\mathrm{SI}$ & Transformation \\
\hline 45 & Faro de Finisterra & Spain & SI & Transformation \\
\hline 48 & Faro de Cabo village & Spain & SI & Transformation \\
\hline 49 & Camarinas & Spain & $\mathrm{SI}$ & Transformation \\
\hline 52 & Beo Peninsula & Spain & $\mathrm{SI}$ & Transformation \\
\hline 53 & Punta Frouxeira lighthouse & Spain & SI & Transformation \\
\hline 54 & Punta Frouxeira beach & Spain & $\mathrm{SI}$ & Transformation \\
\hline 59 & Playa de San Antolin & Spain & SF & Transformation \\
\hline
\end{tabular}

*SI and SF indicate self-incompatible or self-fertile respectively.

were pre-treated by soaking in concentrated sulphuric acid for ten minutes prior to surface sterilization. This acid scarification allows seed to subsequently imbibe in preparation for germination [43]. Acid was thoroughly washed from seed by rinsing with water and then seeds were surface sterilized by soaking in bleach ( $5 \%$ available chlorine) for approximately 10 minutes followed by up to 6 washes in sterile distilled water. The seeds were then allowed to imbibe overnight at room temperature or for up to 3 days at $4^{\circ} \mathrm{C}$. Seeds were dissected under a binocular microscope as described by White and Voisey [29] to separate the imbibed cotyledons. Excised cotyledons were placed adaxial side uppermost on the plant growth media.

\section{Plant growth media and shoot regeneration}

The basal medium for all in vitro culture contained Murashige and Skoog (MS) salts [44] and B5 vitamins
[45] supplemented with $30 \mathrm{gl}^{-1}$ maltose and $8 \mathrm{gl}^{-1}$ phytoagar (Gibco, BRL) and the combinations of PGRs as described below. Treatments containing PGRs; 6Benzyladenine (BA), Indole-3-butyric Acid (IBA), Napthaleneacetic acid (NAA) and Thidiazuron (TDZ) were used in a media optimization experiment which comprised forty two media. These media contained combinations of the following: 0.5 to $2.0 \mathrm{mgl}^{-1} \mathrm{BA}$ and 0.1 to $1.0 \mathrm{mgl}^{-1} \mathrm{IBA} ; 0.5$ to $2.0 \mathrm{mgl}^{-1} \mathrm{BA}$ and 0.1 to $1.0 \mathrm{mgl}^{-1}$ NAA; 0.01 to $1.0 \mathrm{mgl}^{-1} \mathrm{TDZ}$ and 0.1 to $1.0 \mathrm{mgl}^{-1}$ IBA; 0.01 to $1.0 \mathrm{mgl}^{-1} \mathrm{TDZ}$ and 0.1 to $1.0 \mathrm{mgl}^{-1} \mathrm{NAA}$. All media were adjusted to a $\mathrm{pH}$ of 5.8 with $\mathrm{KOH}$ before autoclaving at $121^{\circ} \mathrm{C}$ for 15 minutes. PGRs were filter sterilized and added after autoclaving. All experiments used $9.0 \mathrm{~cm}$ Petri dishes sealed with catering film and were conducted in culture rooms set to a constant temperature of $25^{\circ} \mathrm{C}$ with a 16 hour photoperiod using a combination of 
Cool White and Grolux fluorescent lamps at light intensity of $60 \mathrm{~mol} \mathrm{~m}^{-2} \mathrm{~s}^{-1}$.

\section{Bacterial strains and plasmids}

The binary vector pHZBar-intGUS was used for all transformation experiments. This vector, a derivative of pART27 [46], contains the bar selection gene expressed from the CaMV $35 \mathrm{~S}$ promoter and a gusA reporter gene also under the expression of the CaMV $35 \mathrm{~S}$ promoter. The plasmid was transferred into A. tumefaciens strain GV3101 [47] by triparental mating [48]. Transformants were selected on YM plates containing $200 \mathrm{mgl}^{-1}$ Spectinomycin and successful mobilisation of the plasmid into Agrobacterium was confirmed by restriction mapping following preparation of plasmid DNA from the bacterial culture. A starter culture was prepared using the method of Tingay et al. [49] and used to provide a standardized inoculum for transformation experiments.

\section{Agrobacterium-mediated transformation}

A culture of pHZBar-intGUS/GV3101 was added to $25 \mathrm{ml}$ of Mannitol Glutamate Luria (MGL) broth containing $100 \mathrm{mgl}^{-1}$ Spectinomycin. Bacterial cultures were grown overnight (16 hours) on a rotary shaker $(200 \mathrm{rpm})$ at $28^{\circ} \mathrm{C}$. Cultures were harvested by centrifugation $(3000 \times \mathrm{g})$, the supernatant removed and the cells re-suspended in a $5 \mathrm{ml}$ solution of $10 \mathrm{mM} \mathrm{MgSO}_{4}$ in preparation for plant transformation. Freshly dissected cotyledons were inoculated with $3 \mu \mathrm{l}$ of Agrobacterium suspension and co-cultivated for 72 hours at $25^{\circ} \mathrm{C}$ under a 16 hour photoperiod.

\section{Selection of transformed plants}

Co-cultivated cotyledons were transferred to plates containing regeneration medium supplemented with $2.5 \mathrm{mgl}^{-1}$ ammonium glufosinate (Fluka) and $300 \mathrm{mgl}^{-1}$ Timentin (GlaxoSmithKilne) and returned to the culture room. Regenerated shoots were transferred to rooting medium (0.1 mgl $\mathrm{ma}^{-1} \mathrm{BA}, 0.05 \mathrm{mgl}^{-1} \mathrm{NAA}$ ) and then to hormone-free basal medium supplemented with ammonium glufosinate and Timentin for further growth before transfer to the greenhouse. Regenerating shoots were subcultured to fresh media containing selection at two weekly intervals.

\section{DNA extraction and PCR}

PCR analysis was performed to confirm stable integration of the T-DNA into the genome for plants recovered from transformation experiments. Genomic DNA was extracted from approximately $50 \mathrm{mg}$ of in vitro grown leaves using the Genomic DNA Mini Kit (Geneaid). Primer pairs specific to the ocs3' polyadenylation signal (ocs3' $-1 \mathrm{f}, 5^{\prime}$ GATATGCGAGACGCCTATGA-3'; ocs 3' -1r, 5' -GAGTT CCCTTCAGTGAACGT-3'), bar gene (bar-3, 5' -CAGGA ACCGCAGGAGTGGA-3'; bar-4, 5' -CCAGAAACCCAC
GTCATGCC-3') and gusA reporter gene (gusA-1f, 5'AACAGTTCCTGATTAACCACAAACC-3'; gusA-1r, 5' GCCAGAAGTTCTTTTTCCAGTACC-3') were used to produce amplification products of $439 \mathrm{bp}, 372 \mathrm{bp}$ and 634 bp respectively. Control reactions comprising plasmid DNA template, non-transformed plant DNA or water only were also included. The protocol for PCR reactions consisted of: an initial denaturation of $94^{\circ} \mathrm{C}$ for 5 minutes, 30 cycles of $95^{\circ} \mathrm{C} 30 \mathrm{~s}, 55^{\circ} \mathrm{C} 15 \mathrm{~s}, 72^{\circ} \mathrm{C} 1 \mathrm{~min}$, and an extension of $72^{\circ} \mathrm{C}$ for $10 \mathrm{~min}$. Amplification products were resolved on $1.0 \%$ agarose gels by gel electrophoresis in TAE buffer and visualized with a Bio-Rad Gel Doc imaging sytem.

\section{Histochemical GUS assay}

GUS activity was determined in the leaves of primary transformed $\left(\mathrm{T}_{0}\right)$ plants using a histochemical assay [50]. The reagent X-Gluc (1.0 mg/ml, pH7.0, Duchefa) was used to stain leaves of in vitro plants regenerated under ammonium glufosinate selection. A negative control of non-transformed leaf tissue and a positive control (transgenic tissue expressing GUS from the CaMV35S promoter) were included in the assay.

\section{Southern blot analysis}

Genomic DNA was extracted from leaf material of greenhouse grown plants for Southern blot hybridization using the method of [51]. DNA $(20 \mu \mathrm{g})$ was digested with EcoRV, separated on a $0.8 \%$ agarose gel and transferred onto a nylon membrane (Roche) using capillary transfer with $0.4 \mathrm{~N} \mathrm{NaOH}$. A 634 bp probe to the gusA gene using primers gusA-1f and gusA-1r was prepared using the DIG PCR synthesis kit. Prehybridization (1 hour) and hybridization (12 hours) were performed at $45^{\circ} \mathrm{C}$ using standard buffers (Roche). Detection was achieved using a non-radioactive method according to the manufacturer's protocol with CDP-Star as the chemiluminescent substrate. Light signals were detected on X-ray film (Roche).

\section{Additional files}

Additional file 1: Table S1. Regeneration frequencies from explants of AZ4270 achieved for each PGR treatment.

Additional file 2: Figure S1. Diagram of the T-DNA of pHZBar-intGUS.

\section{Abbreviations}

BA: 6-Benzyladenine; GUS: $\beta$-Glucuronidase; IBA: Indole-3-butyric Acid; MS: Murashige and Skoog medium; NAA: Napthaleneacetic acid; PCR: Polymerase chain reaction; PGR: Plant growth regulator; TDZ: Thidiazuron; X-Gluc: 5-bromo-4-chloro-3-indoyl glucuronide.

\section{Competing interests}

The authors declare they have no competing interests. 


\section{Authors' contributions}

KAR, CSJ and GB designed the experiments. KAR constructed the vector pHZBar-intGUS, performed the Southern Blot Hybridisation and wrote the manuscript. DAM performed all tissue culture, genetic transformation experiments and maintained plants in the greenhouse. All authors read and approved the final manuscript.

\section{Acknowledgements}

The authors wish to thank; Drs Warren Williams and Mike Hay for useful discussions on the culture of $T$. occidentale and providing early access to seed from the Margot Forde Germplasm Centre at AgResearch, Professor Tony Conner for critical assessment of the manuscript; and the Pastoral Genomics Research Consortium and Ministry of Science and Innovation for jointly funding the research.

\section{Research area}

Model species for white clover genomics.

\section{Author details}

1AgResearch Ltd, Grasslands Research Centre, Private Bag 11008, Palmerston North 4442, New Zealand. ²Pastoral Genomics, c/o Grasslands Research Centre, Private Bag 11008, Palmerston North 4442, New Zealand.

Received: 2 May 2013 Accepted: 1 July 2013

Published: 10 July 2013

\section{References}

1. Woodfield DR, Caradus JR: Genetic improvement in white clover representing six decades of plant breeding. Crop Sci 1994, 34:1205-1213.

2. Forde MB, Hay MJM, Brock JL: Development and growth characteristics of temperate perennial legumes. In Persistence of forage legumes: Proceedings of a trilateral workshop at Honolulu, Hawaii, on 18-22 July, 1988. Madison, Wisconsin: American Society of Agronomy, Crop Science Society of America, Soil Science Society of America; 1989:91-109.

3. Thomas RG, Hay MJM: Evidence suggests plagiotropic clonal species have evolved a branching physiology emphasizing regulation by nodal roots. Evol Ecol 2004, 18:409-428.

4. Williams WM, Ellison NW, Ansari HA, Verry IM, Hussain SW: Experimental evidence for the ancestry of allotetraploid Trifolium repens and creation of synthetic forms with value for plant breeding. BMC Plant Biol 2012, 12:55.

5. White DWR, Woodfield DR, Dudas B, Forster RLS, Beck DL: White clover molecular genetics. Plant Breeding Reviews 2000, 17:191-223.

6. Jenkins CLD, Snow AJ, Simpson RJ, Higgins TJ, Jacques NA, Pritchard J, Gibson J, Larkin PJ: Fructan formation in transgenic white clover expressing a fructosyltransferase from Streptococcus salivarius. Funct Plant Biol 2002, 29:1287-1298.

7. Christiansen P, Gibson JM, Moore A, Pedersen C, Tabe L, Larkin PJ: Transgenic Trifolium repens with foliage accumulating the high sulphur protein, sunflower seed albumin. Transgenic Res 2000, 9:103-113.

8. Sharma SB, Hancock KR, Baling PM, White DWR: Expression of a sulfur-rich maize seed storage protein, $\delta$-zein, in white clover (Trifolium repens) to improve forage quality. Mol Breed 1998, 4:435-448.

9. Voisey CR, Dudas B, Biggs R, Burgess EPJ, Wigley PJ, McGregor PG, Lough TJ, Beck DL, Forster RLS, White DWR: Transgenic pest and disease resistant white clover plants. In Molecular Breeding of Forage Crops: Proceedings of the 2nd International Symposium, Molecular Breeding of Forage Crops, Lorne and Hamilton, Victoria, Australia, 19-24 November, 2000. Edited by Spangenberg G. Dordrecht: Kluwer Academic Publishers; 2001:239-250.

10. Panter S, Chu PG, Ludlow E, Garrett R, Kalla R, Jahufer MZZ, de Lucas Arbiza A, Rochfort S, Mouradov A, Smith KF, Spangenberg G: Molecular breeding of transgenic white clover (Trifolium repens L.) with field resistance to Alfalfa mosaic virus through the expression of its coat protein gene. Transgenic Res 2012, 21:619-632.

11. Lee RWH, Strommer J, Hodgins D, Shewen PE, Niu Y, Lo RYC: Towards development of an edible vaccine against bovine pneumonic pasteurellosis using transgenic white clover expressing a Mannheimia haemolytica A1 leukotoxin 50 fusion protein. Infect Immun 2001, 69:5786-5793

12. Sato S, Nakamura Y, Asamizu E, Isobe S, Tabata S: Genome sequencing and genome resources in model legumes. Plant Physiol 2007, 144:588-593.
13. Spangenberg GC, Forster JW, Edwards D, John U, Mouradov A, Emmerling M, Batley J, Felitti S, Cogan NOI, Smith KF, Dobrowolski MP: Future directions in the molecular breeding of forage and turf. In Molecular Breeding for the Genetic Improvement of Forage Crops and Turf: Proceedings of the 4th international symposium on the molecular breeding of forage and turf, a satellite workshop of the XXth International Grassland Congress, Aberystwyth, Wales, July 2005. Edited by Humphreys MO. Wageningen: Wageningen Academic Publishers; 2005:83-97.

14. Williams WM, Easton HS, Jones CS: Future options and targets for pasture plant breeding in New Zealand. N Z J Agric Res 2007, 50:223-248.

15. Ding $Y L$, Aldao-Humble $G$, Ludlow E, Drayton M, Lin YH, Nagela J, Dupal M, Zhao G, Pallaghy C, Kalla R, et al: Efficient plant regeneration and Agrobacterium-mediated transformation in Medicago and Trifolium species. Plant Sci 2003, 165:1419-1427.

16. Larkin PJ, Gibson JM, Mathesius U, Weinman JJ, Gartner E, Hall E, Tanner GJ, Rolfe BG, Djordjevic MA: Transgenic white clover. Studies with the auxinresponsive promoter, $\mathrm{GH} 3$, in root gravitropism and lateral root development. Transgenic Res 1996, 5:325-335.

17. Voisey CR, White DWR, Dudas B, Appleby RD, Ealing PM, Scott AG: Agrobacterium-mediated transformation of white clover using direct shoot organogenesis. Plant Cell Rep 1994, 13:309-314.

18. White DWR, Greenwood D: Transformation of the forage legume Trifolium repens L. using binary Agrobacterium vectors. Plant Mol Biol 1987, 8:461-469.

19. Williams WM, Griffiths AG, Hay MJM, Richardson KA, Ellison NW, Rasmussen S, Verry TM, Collette V, Hussain SW, Thomas RG, et al: Development of Trifolium occidentale as a plant model system for perennial clonal species. In Molecular Breeding of Forage and Turf: Proceedings of the 5th International Symposium on the Molecular Breeding of Forage and Turf, Sapporo, Japan, 2007. Edited by Yamada T, Spangenberg G. New York: Springer; 2009:45-53.

20. Charlesworth D, Willis JH: The genetics of inbreeding depression. Nat Rev Genet 2009, 10:783-796.

21. Woodfield DR, White DWR: Breeding strategies for developing transgenic white clover cultivars. In White clover: New Zealand's competitive edge: Joint symposium, Lincoln University, New Zealand, 21-22 November 1995, Volume Volume No.6. Christchurch: Agronomy Society of New Zealand; 1996:125-130. Grassland Research and Practice Series.

22. Young ND, Mudge J, Ellis THN: Legume genomes: More than peas in a pod. Curr Opin Plant Biol 2003, 6:199-204.

23. Coombe DE: Trifolium occidentale, a new species related to $T$. repens $\mathrm{L}$. Watsonia 1961, 5:68-87.

24. Griffiths AG, Moraga $R$, Khan A: De novo genome sequencing of white clover (Trifolium repens L.) [abstract]. In Plant and Animal Genome XXI: 12-16 January 2013. San Diego, CA: San Diego, CA; 2013.

25. Aina O, Quesenberry K, Gallo M: In vitro induction of tetraploids in Arachis paraguariensis. Plant Cell Tiss Org Cult 2012, 111:231-238.

26. Wu JH, Ferguson AR, Murray BG: Manipulation of ploidy for kiwifruit breeding: In vitro chromosome doubling in diploid Actinidia chinensis Planch. Plant Cell Tiss Org Cult 2011, 106:503-511.

27. Williams WM, Ansari HA, Hussain SW, Ellison NW, Williamson ML, Verry IM: Hybridization and introgression between two diploid wild relatives of white clover, Trifolium nigvescens viv. and T. occidentale Coombe. Crop Sci 2008, 48:139-148.

28. Birch RG: Plant transformation: Problems and strategies for practical application. Annu Rev Plant Biol 1997, 48:297-326.

29. White DWR, Voisey C: Prolific direct plant regeneration from cotyledons of white clover. Plant Cell Rep 1994, 13:303-308.

30. Chabaud M, Larsonneau C, Marmouget C, Huguet T: Transformation of barrel medic (Medicago truncatula Gaertn.) by Agrobacterium tumefaciens and regeneration via somatic embryogenesis of transgenic plants with the MtENOD12 nodulin promoter fused to the gus reporter gene. Plant Cell Rep 1996, 15:305-310.

31. Trieu AT, Harrison MJ: Rapid transformation of Medicago truncatula: Regeneration via shoot organogenesis. Plant Cell Rep 1996, 16:6-11.

32. Lohar DP, Schuller K, Buzas DM, Gresshoff PM, Stiller J: Transformation of Lotus japonicus using the herbicide resistance bar gene as a selectable marker. J Exp Bot 2001, 52:1697-1702

33. Stiller J, Martirani L, Tuppale S, Chian RJ, Chiurazzi M, Gresshoff PM: High frequency transformation and regeneration of transgenic plants in the model legume Lotus japonicus. J Exp Bot 1997, 48:1357-1365. 
34. Pickens KA, Cheng ZM, Trigiano RN: Axillary bud proliferation and organogenesis of Euphorbia pulchurrima Winter Rose ${ }^{\mathrm{TM}}$. In Vitro Cell Dev Biol Plant 2005, 41:770-774.

35. Caboni E, Tonelli MG, Lauri P, D'Angeli S, Damiano C: In vitro shoot regeneration from leaves of wild pear. Plant Cell Tiss Org Cult 1999, 59:1-7.

36. Debnath SC: Developing a scale-up system for the in vitro multiplication of thidiazuron-induced strawberry shoots using a bioreactor. Can J Plant Sci 2008, 88:737-746.

37. Beattie LD, Garrett RG: Adventitious shoot production from immature embryos of white clover. Plant Cell Tiss Org Cult 1995, 42:67-72.

38. Somers DA, Samac DA, Olhoft PM: Recent advances in legume transformation. Plant Physiol 2003, 131:892-899.

39. Herman EB: Recent advances in plant tissue culture, VIII. Microbial contaminants in plant tissue cultures: solutions and opportunities: 1996-2003. Shrub Oak: Agritech Consultants, Inc; 2004

40. Leifert C, Cassells AC: Microbial hazards in plant tissue and cell cultures. In Vitro Cell Dev Biol Plant 2001, 37:133-138.

41. Mouradov A, Panter S, Labandera M, Ludlow E, Emmerling M, Spangenberg G: Clovers (Trifolium spp.). Methods Mol Biol 2006, 343:325-335.

42. Roberts NJ, Scott RW, Winichayakul S, Roldan M: Modified neutral lipid encapsulating proteins and uses thereof. Agresearch Limited ed., C12N001529 | C07K0014415 | C12N001579th edition. CA: Agresearch Limited, Hamilton NZ; 2011.

43. Kimura E, Islam MA: Seed scarification methods and their use in forage legumes. Res I Seed Sci 2012, 5:38-50

44. Murashige T, Skoog F: A revised medium for rapid growth and bio assays with tobacco tissue cultures. Physiol Plant 1962, 15:473-497.

45. Gamborg OL, Miller RA, Ojima K: Nutrient requirements of suspension cultures of soybean root cells. Exp Cell Res 1968, 50:151-158.

46. Gleave AP: A versatile binary vector system with a T-DNA organisational structure conducive to efficient integration of cloned DNA into the plant genome. Plant Mol Biol 1992, 20:1203-1207.

47. Koncz C, Schell J: The promoter of TL-DNA gene 5 controls the tissuespecific expression of chimaeric genes carried by a novel type of Agrobacterium binary vector. Mol Gen Genet 1986, 204:383-396.

48. Ditta G, Stanfield S, Corbin D, Helinski DR: Broad host range DNA cloning system for Gram-negative bacteria: Construction of a gene bank of Rhizobium meliloti. Proc Natl Acad Sci USA 1980, 77:7347-7351.

49. Tingay S, McElroy D, Kalla R, Fieg S, Wang M, Thornton S, Brettell R: Agrobacterium tumefaciens-mediated barley transformation. Plant J 1997 11:1369-1376.

50. Jefferson RA, Kavanagh TA, Bevan MW: GUS fusions: beta-glucuronidase as a sensitive and versatile gene fusion marker in higher plants. EMBO J 1987, 6:3901-3907.

51. Doyle J, Doyle J: A rapid total DNA preparation procedure for fresh plant tissue. Focus 1990, 12:13-15.

doi:10.1186/1746-4811-9-25

Cite this article as: Richardson et al.: Genetic transformation of western clover (Trifolium occidentale D. E. Coombe.) as a model for functional genomics and transgene introgression in clonal pasture legume species. Plant Methods 2013 9:25.

\section{Submit your next manuscript to BioMed Central and take full advantage of:}

- Convenient online submission

- Thorough peer review

- No space constraints or color figure charges

- Immediate publication on acceptance

- Inclusion in PubMed, CAS, Scopus and Google Scholar

- Research which is freely available for redistribution

Submit your manuscript at www.biomedcentral.com/submit
C Biomed Central 